\title{
RANCANG BANGUN DAN UJICOBA PENGERING SURYA TIPE KOLEKTOR TABUNG VAKUM (EVACUATED TUBE COLLECTOR)
}

\section{DESIGN AND FABRICATION OF DRYER WITH EVACUATED TUBE COLLECTOR TYPE}

\author{
Sari Farah Dina, Siti Masriani Rambe, Azwardi, Edwin Harianto Sipahutar \\ Baristand Industri Medan, JI Sisingamangaraja No.24 Medan \\ e-mail : siti masriani@yahoo.com; sfdina1@yahoo.com
}

Diterima: 18 Mei 2018; Direvisi: 30 Mei 2018- 12 Juni 2018; Disetujui: 28 Juni 2018

\begin{abstract}
Abstrak
Penelitian tentang Rancang Bangun dan Ujicoba Pengering Surya Tipe Kolektor Tabung Vakum untuk mengeringkan kopi telah dilakukan. Penelitian ini dilakukan dengan melalui tahap perumusan, perancangan, perangkaian dan uji coba alat menggunakan kopi sebagai bahan untuk dikeringkan. Hasil uji coba diperoleh suhu udara pengering yang lebih tinggi maka waktu pengeringan dapat lebih singkat dan laju pengeringan lebih besar. Hasil rancang bangun pengering surya ini selanjutnya diuji coba untuk mengeringkan kopi dari kadar air 52,80\% hingga kadar air $12,30 \%$, dengan sistem konveksi paksa yang memvariasikan kecepatan udara 2-6 m/sec. Selama pelaksanaan pengeringan kondisi cuaca rata-rata berada pada rentang 143-855 Watt/m2, temperatur lingkungan $28-35^{\circ} \mathrm{C}$. Temperatur udara didalam kolektor $85-192{ }^{\circ} \mathrm{C}$ dan temperatur didalam ruang pengering adalah $35-78{ }^{\circ} \mathrm{C}$. Hasil uji coba untuk pengeringan biji kopi menunjukkan bahwa kecepatan udara berbanding lurus dengan laju pengeringan, efisiensi kolektor dan berbanding terbalik dengan waktu pengeringan dan konsumsi energi spesifik (KES).
\end{abstract}

Kata kunci : kinerja, kolektor, pengering, tabung vakum

\begin{abstract}
Research of design of solar dryer with evacuated tube collector for drying coffee bean has been done. This research is done through the stage of formulation, design, circuit and testing tools using coffee as material to be dried.Test results of a solar dryer designed then is being used for drying coffee bean (moisture content from $52.80 \%$ to $12.30 \%)$, with forced convection system which the air speed are varied of 2-6 $\mathrm{m} / \mathrm{sec}$. During the drying process, the average weather conditions are in the range 143-855 Watt / m2, ambient temperature of 28-36 ${ }^{\circ} \mathrm{C}$. The air temperature in the collector are $85-192{ }^{\circ} \mathrm{C}$ and the temperature in the drying chamber are $35-78{ }^{\circ} \mathrm{C}$. The results showed that air drying velocity is directly proportional to the drying rate and collector efficiency but inversely to drying time and specific energy consumption (SEC).
\end{abstract}

Keywords : performance, collector, dryers, evacuated tube

\section{PENDAHULUAN}

Energi surya merupakan sumber energi termal utama yang digunakan untuk mengeringkan produk hasil pertanian.

Beberapa upaya untuk meningkatkan efektifitas pengeringan berbasis matahari telah dilakukan dan telah menjadi alternatif yang menjanjikan serta telah menunjukkan peningkatan efisiensi pengeringan (Fudholi dkk, 2010). Beberapa penelitian tentang kinerja pengering surya dengan kolektor plat datar (Darshit dkk,2011) dan penyimpanan bahan panas (Saravanakumar dkk, 2011) telah $\begin{array}{llr}\text { dilaporkan yang bertujuan untuk } \\ \text { memperbaiki } & \text { sistem pengeringan }\end{array}$ tradisional.

Pengering surya menggunakan kolektor surya telah banyak dikembangkan, baik jenis kolektor pelat datar maupun kolektor tabung vakum (KTV). KTV diketahui lebih efisien dibanding pelat datar dikarenakan dapat menurunkan tingkat kehilangan panas akibat konveksi ke lingkungan. Oleh karenanya pengering surya tipe KTV dapat menghasilkan udara yang akan dikirim ke ruang pengering memiliki suhu lebih tinggi dibanding suhu 
udara hasil pemanasan dari kolektor pelat datar (Vendan dkk, 2012).

Untuk beberapa produk pertanian ataupun hasil tangkapan nelayan bahkan memerlukan kondisi pengeringan (suhu) sekitar $100^{\circ} \mathrm{C}$ atau lebih. Pada kondisi demikian pengering surya tipe KTV adalah yang terbaik (Hossain dkk, 2012). Pengeringan wortel, apel dan aprikot menggunakan KTV telah dilakukan untuk mendapatkan kajian analisa kinerja termodinamika (Lamnatou dkk, 2012). Pengeringan cabai menggunakan pengering surya tipe kolektor KTV telah mampu mempersingkat waktu pengeringan dibandingkan dengan penjemuran langsung (Sundari dkk, 2013).

Salah satu komoditi hasil pertanian yang menjadi salah satu ikon Propinsi Sumatera Utara adalah kopi yang berasal dari kabupaten Tanah Karo dan kabupaten Dairi. Penanganan pasca panen kopi di kedua kabupaten ini masih menggunakan sistem konvensional (penjemuran langsung) sehingga selain memerlukan waktu lebih lama, lahan lebih luas juga memiliki tingkat hygiene yang rendah.

Meski pengeringan terbaik adalah dengan matahari namun untuk mendapatkan kualitas terbaik, suhu pengeringan adalah sekitar $70^{\circ} \mathrm{C}$ (Jinap dkk, 1994). Oleh karenanya pengering surya tipe tabung vakum menjadi pilihan yang tepat untuk mengeringkan biji kopi. Atas dasar pertimbangan ini, maka penelitian rancang bangun pengering surya tipe kolektor tabung vakum dilakukan.

Tujuan penelitian ini melakukan perancangan dan pabrikasi pengering surya tipe KTV pada rasio luas kolektor terhadap volume ruang pengering adalah lebih besar dari 3 (teori); juga melakukan kajian performansi untuk melihat pengaruh kecepatan aliran udara terhadap waktu pengeringan biji kopi.

\section{BAHAN DAN METODE}

Perancangan merupakan kegiatan awal dari usaha merealisasikan suatu produk yang kebutuhannya dibutuhkan oleh masyarakat. Setelah perancangan selesai maka kegiatan yang menyusul adalah pembuatan produk seperti pengering. Cara merancang pada penelitian ini terdiri dari 4 tahap atau fase, yang masing-masing terdiri dari beberapa langkah (Pahl dan Beitz). Ke4 fase tersebut adalah: 1). Fase Perumusan (Formulation Phase), 2). Fase Fungsi (Functional Phase), 3). Fase Perancangan (Design Phase) dan 4). Hasil (Result). Perencanaan alat pengering surya tipe kolektor tabung vakum meliputi ruang pengering, sistem kolektor surya dan sistem aliran udara. Proses pengeringan berlangsung secara konveksi paksa sehingga diperlukan blower untuk sirkulasi udara menuju dan keluar ruang pengering. Gambar desain pengering surya tipe kolektor tabung vakum yang telah dibuat dapat dilihat pada Gambar 1.

Alur proses kegiatan Desain dan Pabrikasi Pengering Surya Tipe KTV yang dilakukan selanjutnya dijelaskan pada diagram alir penelitian sebagai berikut pada Gambar 2. Udara kering yang dialirkan fan kedalam ruang pengering selanjutnya menaikkan suhu biji kopi hingga terjadi penguapan. Uap air berpindah ke udara pengering dan selanjutnya dibuang /dikeluarkan melalui celah keluar udara. 


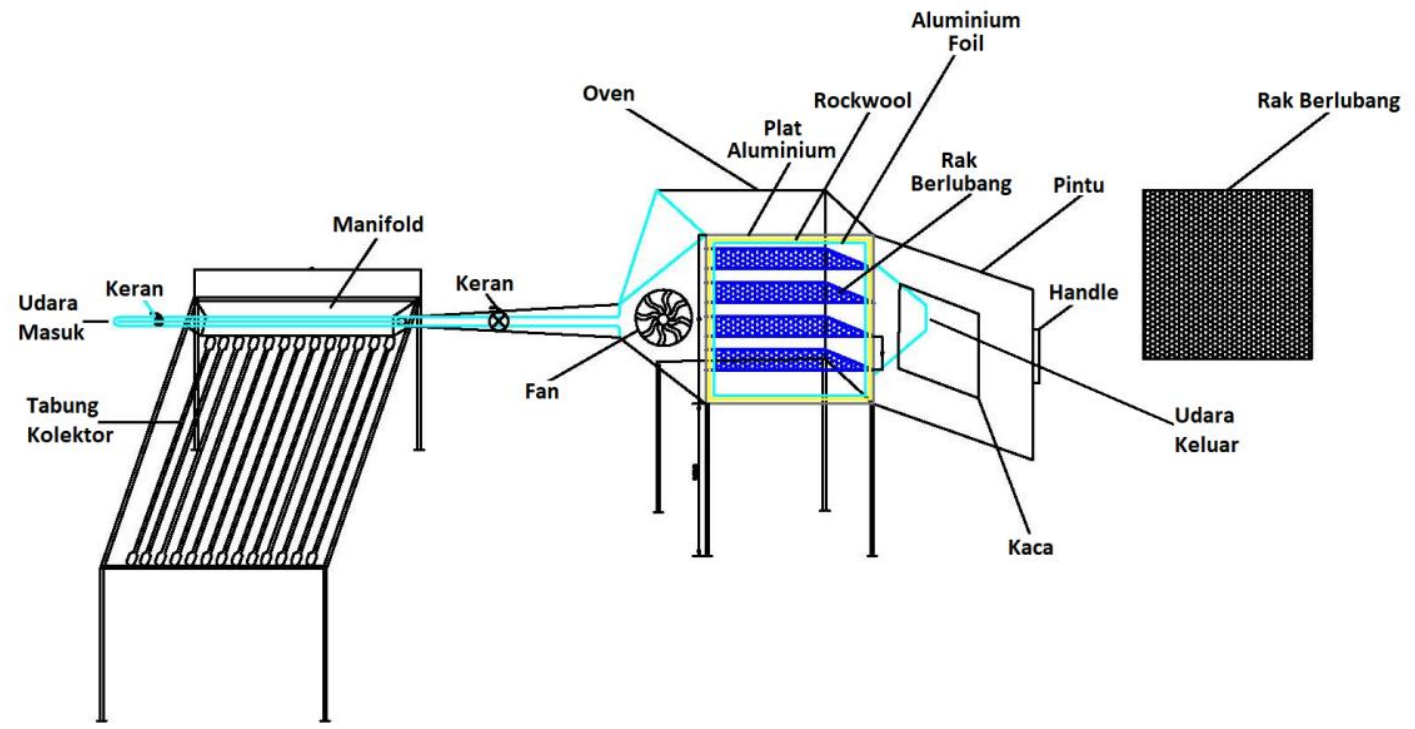

Gambar 1. Pengering Surya Tipe Kolektor Tabung Vakum

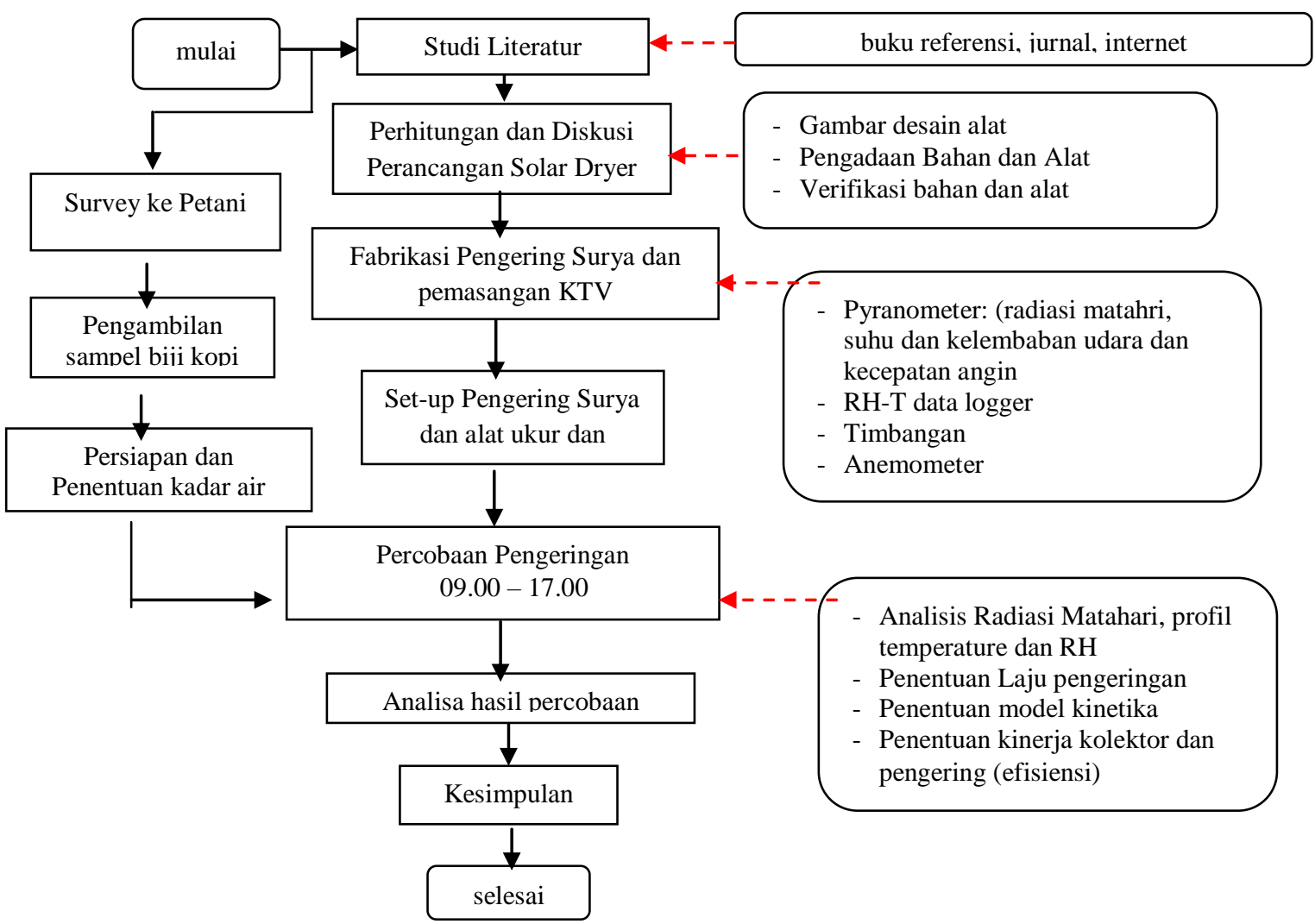

Gambar 2. Diagram Alir Penelitian

Penentuan kapasitas/ukuran pengering didasarkan pada perhitungan parameter desain sebagai berikut (Sundari dkk, 2013) :

$$
\mathrm{R}=\mathrm{SA} / \mathrm{V}
$$

dimana:

$$
\begin{array}{ll}
\mathrm{SA} & \text { : luas kolektor } \\
\mathrm{V} & \text { : volume ruang pengering }
\end{array}
$$


Jika rasio ini adalah sama atau lebih besar dari 3 maka dikatakan desain pengering adalah baik. Berdasarkan persamaan 1), ruang pengering didesain dengan dimensi pxlxt adalah $100 \mathrm{~cm} \times 100 \mathrm{~cm} \times 100 \mathrm{~cm}$ yang dibuat dari bahan pelat aluminium tebal $0,35 \mathrm{~mm}$ dan dibagian dalam dilapis rockwool dan aluminium foil. Ruang pengering dilengkapi dengan 4 (empat) buah rak kasa. Kolektor tabung vakum terdiri dari manifold, berupa alat penukar kalor antara pipa tembaga dan udara yang akan dipanaskan. Tabung vakum berjumlah 18 buah terbuat dari gelas kaca (borosilikat) dengan diameter $580 \mathrm{~mm}$ dan panjang $1770 \mathrm{~mm}$

Hasil perancangan dan pembuatan pengering surya tipe tabung vakum ini kemudian diuji coba untuk mengeringkan kopi/kakao dari jam 09.00 sampai dengan jam 17.00. Pengeringan dihentikan jika tidak ada lagi penurunan berat sampel (kondisi setimbang). Selama pengeringan berlangsung, perubahan berat sampel, data temperatur dan $\mathrm{RH}$ ruang pengering, kecepatan aliran udara dan intensitas radiasi direkam. Keseluruhan penelitian yang dilakukan dilaksanakan sesuai diagram alir penelitian seperti pada Gambar 2.

\section{Variabel Diamati}

Pada pelaksanaan desain, pabrikasi dan uji coba pengeringan energi surya tipe KTV, ada beberapa data yang direncakanan akan dikumpulkan dan selanjutnya dilakukan analisis dalam penelitian ini antara lain adalah sebagai berikut:

1. Temperatur $\left({ }^{\circ} \mathrm{C}\right)$

Temperatur yang di ukur adalah temperatur udara ambien, udara masuk (keluar kolektor) dan keluar ruang pengering.

2. $\mathrm{RH}(\%)$

Kelembaban relatif udara didalam ruang pengering.

3. Lama pengeringan ( $\mathrm{t}$ )

Waktu yang dibutuhkan selama proses pengeringan berlangsung.

4. Berat (gram)
Perubahan berat sampel yang dikeringkan ditimbang setiap 30 menit.

5. Kecepatan aliran udara (m/det) Kecepatan aliran udara meuju ruang pengering diukur setiap 30 menit

6. Intensitas Radiasi (Watt $/ \mathrm{m}^{2}$ )

Besarnya intensitas radiasi matahari yang diterima per satuan waktu diukur dan direkam menggnakan

pyranometer.

Teknik Pengukuran, Pengolahan dan Analisis Data

Pengering surya hasil rancang bangun yang telah di pabrikasi selanjutnya diuji coba untuk mengeringkan biji kopi. Setiap pengujian yang dilakukan adalah secara duplo dan data yang diperoleh dianalisis untuk mendapatkan parameter sebagai berikut:

a. Analisa Intensitas Radiasi Vs Temperatur Oven (Ruang Pengering), Kolektor dan Ambient

b. Pengukuran Profil $\mathrm{RH}$ dan Temperatur dan Humiditas Mutlak di dalam Ruang Pengering

c. Penentuan performansi pengeringan: Laju Pengeringan, Efisiensi Termal dan Efisiensi Pengeringan

\section{Ruang Lingkup dan Lokasi Kegiatan}

Lingkup dari penelitian ini meliputi:

a. Studi literatur menggunakan buku-buku referensi, Jurnal Internasional /Nasional terkait originalitas penelitian yang dilakukan.

b. Melakukan survai ke Disperindag dan petani kopi maupun hasil peertanian lainnya di kabupaten/kota di propinsi Sumatera Utara, pengambilan sampel kopi serta melakukan sosialisasi mesin pengering hasil rancang bangun dan perekayasaan tim peneliti Baristand Industri Medan

c. Melalukan perhitungan desain dan pabrikasi mesin pengering atas dasar penentuan dimensi pengering adalah berdasarkan rasio luas kolektor tabung vakum terhadap volume ruang pengering $(\mathrm{R}=\mathrm{SV} / \mathrm{A})>3$.

d. Proses pengeringan berlangsung 
secara intermittent dari $09.00-17.00$ dan dilanjutkan keesokan hari hingga dicapai berat yang diinginkan ( kadar air $\approx 12 \%$ ).

e. Sampel yang dikeringkan adalah biji kopi yang berasal dari kabupaten Tanah Karo Sumatera Utara, yang telah dibuang kulit luarnya dan telah ditentukan kadar air awal terlebih dahulu.

f. Proses pengeringan biji kopi dilakukan dengan memvariasikan kecepatan udara pengering.

g. Melakukan pengumpulan, pengolahan dan evaluasi data untuk uji performansi pengering meliputi: profil temperatur (ambient, kolektor, ruang pengering), intensitas radiasi dan $\mathrm{RH}$ didalam duang pengering, profil moisture ratio terhadap waktu, model kinetika pengeringan, efisiensi pengeringan dan konsumsi energi spesifik pengeringan kopi.

h. Pembuatan Laporan

\section{Lokasi Kegiatan}

Penelitian ini dilakukan selama 10 (sepuluh) bulan mulai dari Januari 2017 sampai dengan Desember 2017. Lokasi penelitian bertempat di Balai Riset dan Standardisasi Industri Medan dan Laboratorium Energi Departemen T. Mesin Institut Teknologi Medan Sumatera Utara.

\section{HASIL DAN PEMBAHASAN}

\section{Hasil Rancang Bangun dan Uji Coba Pengering Surya untuk Mengeringkan Biji Kopi}

Dasar perancangan dimensi ruang pengering adalah berdasarkan persamaan 1 (Sundari dkk, 2013) yakni perbandingan antara luas kolektor tabung vakum terhadap volume ruang pengering:

$$
\mathrm{R}=\mathrm{SA} / \mathrm{V} \text { adalah }>3
$$

dimana SA adalah luas kolektor tabung vakum dan $\mathrm{V}$ adalah volume ruang pengering.

Kolektor tabung vakum yang dipilih memiliki spesifikasi sebagai berikut
a. Jenis
: tube collector
b. Diameter luar (D), $\mathrm{mm}$
$: 580$
c. Panjang tube $(\mathrm{L}), \mathrm{mm}$
$: 1800$
d. Jumlah tube $(\mathrm{N})$
$: 18$
e. Bahan gelas tube
: borosilikat
Berdasarkan data yang diperoleh, maka luas total tube collector, $\mathrm{SA}=\pi$. D. $\mathrm{L}$. $\mathrm{N}=5,9007 \mathrm{~m}^{2}$. Dimensi Ruang pengering yang dipilih adalah $100 \mathrm{~cm} \times 100 \mathrm{~cm}$ x $100 \mathrm{~cm}$, maka volume ruang pengering adalah $\mathrm{V}=(100 \times 100 \times 100) / 100^{3}=1 \mathrm{~m}^{3}$.

Sehingga nilai $R$ dapatdiperoleh yaitu $R=(5,9007 / 1)=5,9 \rightarrow$ Rasio ini adalah lebih besar dari 3 sehingga dimensi ruang pengering layak untuk dipilih.

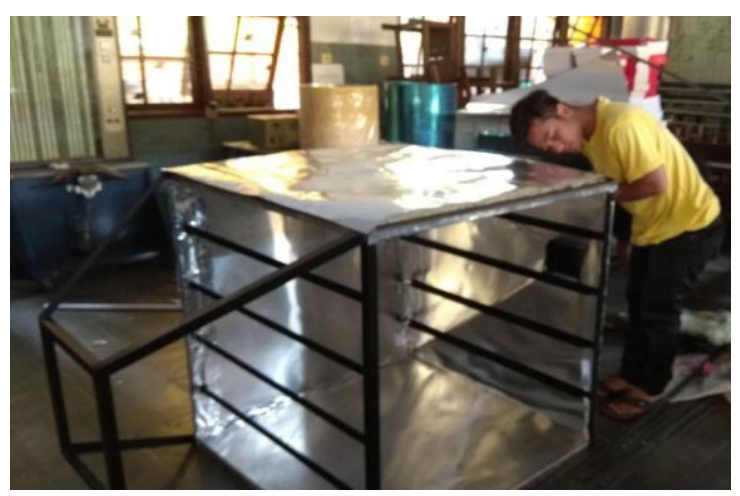

a)

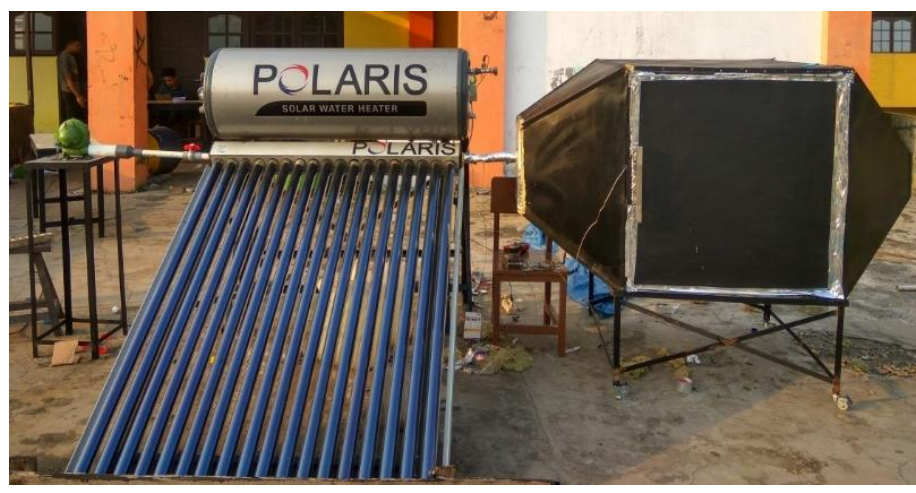

b)

Gambar 3. Rancang Bangun Pengering Surya Tipe Kolektor Tabung Vakum 

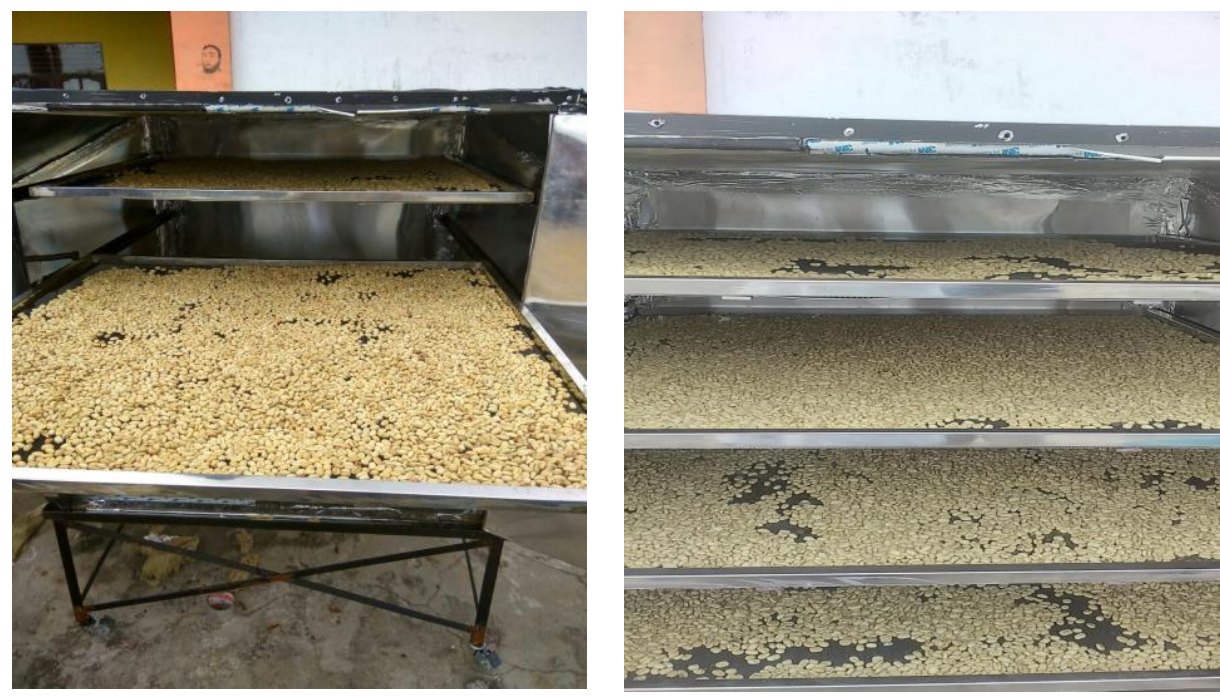

Gambar 4. Proses Ujicoba Pengeringan Biji Kopi pada Pengering Surya Tipe Kolektor Tabung Vakum

Selanjutnya dilakukan pabrikasi ruang pengering dengan dimensi $100 \mathrm{~cm} \times 100$ $\mathrm{cm} \times 100 \mathrm{~cm}$ yang dibuat dari bahan pelat Aluminium tebal $0,35 \mathrm{~mm}$.

\section{Hasil Ujicoba Pengeringan}

Banyak faktor yang berpengaruh dalam proses pengeringan misalnya luas atau volume pengering, temperatur, waktu pengeringan dan faktor lainnya (Jangam SV dkk, 2010). Pada penelitian ini akan membahas tentang pengaruh temperatur pengeringan.

\section{Analisa Intensitas Radiasi Vs Temperatur Oven (Ruang Pengering), Kolektor dan Ambient}

Pada pengujian Run-1 seperti ditunjukkan Gambar 5 dapat dilihat bahwa intensitas radiasi matahari adalah pada rentang $143-851 \mathrm{~W} / \mathrm{m}^{2}$ dan menghasilkan temperatur kolektor hingga maksimum 185 ${ }^{\circ} \mathrm{C}$ dan suhu udara di ruang pengering maksimum $78{ }^{\circ} \mathrm{C}$. Kolektor tabung vakum dapat memberikan panas sensible untuk menaikkan suhu udara pengering dari $36{ }^{\circ} \mathrm{C}$ (maksimum ambient) menjadi $78{ }^{\circ} \mathrm{C}$ (maksimum ruang pengering).

Semakin tinggi intensitas radiasi, maka semakin besar energi termal yang dikonversikan untuk menaikkan suhu udara pengering. Semakin tinggi suhu udara pengering, maka semakin tinggi laju pengeringan dan waktu pengeringan akan lebih singkat Namun jika dilihat dari perbedaan yang cukup signifikan antara suhu kolektor dan ruang pengering (oven) dapat disimpulkan bahwa selama transmisi panas dari kolektor menuju ruang pengering terjadi kehilangan panas.

Pada pengujian Run-2 seperti ditunjukkan Gambar 6 dapat dilihat bahwa intensitas radiasi matahari adalah pada rentang $346-855 \mathrm{~W} / \mathrm{m}^{2}$ dan menghasilkan temperatur kolektor hingga maksimum 192 ${ }^{\circ} \mathrm{C}$ dan suhu udara di ruang pengering maksimum $74{ }^{\circ} \mathrm{C}$. Kolektor tabung vakum dapat memberikan panas sensible untuk menaikkan suhu udara pengering dari $35^{\circ} \mathrm{C}$ (maksimum ambient) menjadi $74{ }^{\circ} \mathrm{C}$ (maksimum ruang pengering). Pada run-2 juga terlihat adanya perbedaan yang cukup signifikan antara suhu kolektor dan ruang pengering (oven) dapat disimpulkan bahwa selama transmisi panas dari kolektor perlu meminimisasi kehilangan panas sehingga temperatur udara menuju ruang pengering dapat lebih tinggi lagi. Secara keseluruhan dapat terlihat bahwa nilai rata-rata temperatur oven sangat dipengaruhi oleh intensitas radiasi yang memanaskan kolektor. 


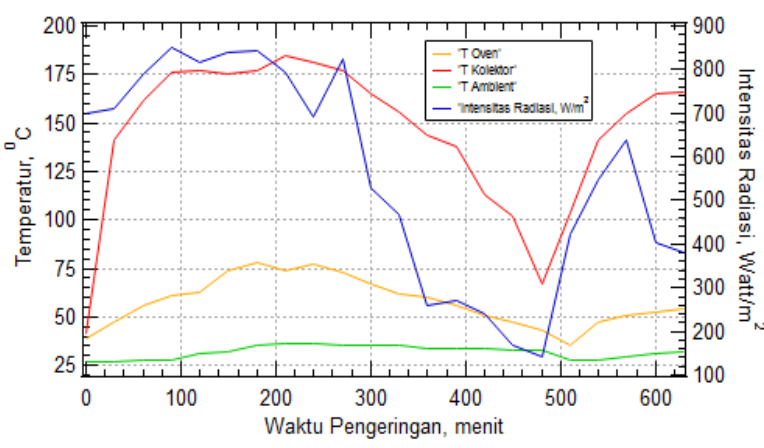

Gambar 5. Pengujian Run-1

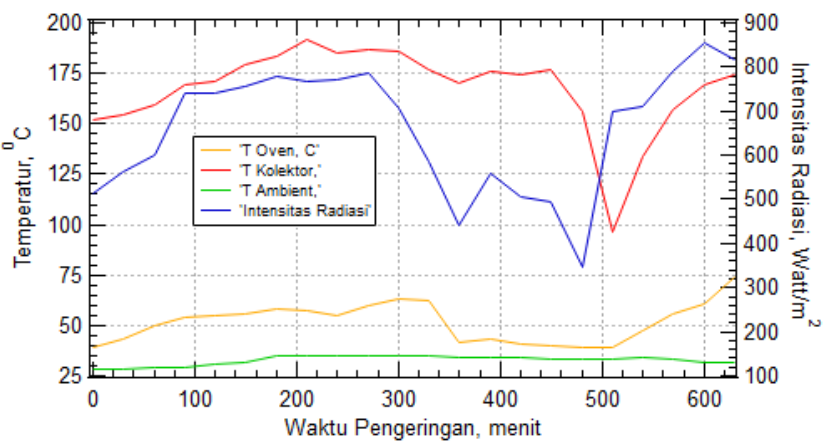

Gambar 6. Pengujian Run-2

Hasil yang diperoleh selama pengujian ini jika dibanding dengan hasil penelitian terdahulu (Venkatesan N, 2014) bahwa hasil rancang bangun penelitian ini memiliki keunggulan dimana pada intensitas radiasi yang lebih kecil $\left(143-851 \mathrm{~W} / \mathrm{m}^{2}\right)$ dibanding yang tertera pada Tabel 1. (302 - 1097 Watt $\left./ \mathrm{m}^{2}\right)$.

Tabel 1. Data Penelitian Pengeringan Labu Menggunakan Kolektor Tabung Vakum (Venkatesan N, 2014)

\begin{tabular}{cccccccccc}
\hline SI.No & Time & $\begin{array}{c}\text { Solar } \\
\text { Insolation } \\
\mathbf{W} / \mathbf{m}^{2}\end{array}$ & $\begin{array}{c}\text { Wind } \\
\text { Velocity } \\
\mathbf{m} / \mathbf{s e c}\end{array}$ & $\begin{array}{c}\mathbf{R H} \\
\text { in } \%\end{array}$ & $\begin{array}{c}\text { Ambient } \\
\text { Temp }{ }^{\circ} \mathbf{C}\end{array}$ & $\begin{array}{c}\text { ETC } \\
\text { Inlet }\end{array}$ & $\begin{array}{c}\text { ETC } \\
\text { outlet } \\
{ }^{\circ} \mathbf{C}\end{array}$ & $\begin{array}{c}\text { Drier } \\
\text { Inlet } \\
{ }^{\circ} \mathbf{C}\end{array}$ & $\begin{array}{c}\text { Drier } \\
\text { Outlet } \\
{ }^{\circ} \mathbf{C}\end{array}$ \\
\hline 1 & 10.00 & 912 & 0.55 & 60 & 31 & 34.5 & 66.0 & 70.4 & 40.9 \\
2 & 11.00 & 1097 & 0.63 & 47.5 & 42 & 46.0 & 78.4 & 72.3 & 60.5 \\
3 & 12.00 & 1071 & 0.46 & 44.5 & 43 & 48.0 & 80.7 & 74.6 & 56.2 \\
4 & 1.00 & 1032 & 0.61 & 41 & 32 & 43.0 & 81.4 & 76.3 & 65.2 \\
5 & 2.00 & 846 & 0.76 & 56 & 27 & 38.0 & 73.4 & 70.6 & 60.3 \\
6 & 3.00 & 471 & 0.97 & 57 & 30 & 34.0 & 58.9 & 58.8 & 50.6 \\
7 & 4.00 & 421 & 1.5 & 56.5 & 31 & 34.0 & 59.2 & 56.6 & 48.4 \\
8 & 5.00 & 302 & 2.64 & 58.5 & 29 & 32.0 & 47.4 & 46.9 & 39.0 \\
9 & 10.00 & 899 & 0.52 & 64 & 30 & 35.5 & 68.0 & 62.7 & 52.0 \\
10 & 11.00 & 1037 & 0.84 & 42.5 & 33 & 41.0 & 91.0 & 84.9 & 72.8 \\
11 & 12.00 & 1078 & 1.2 & 42 & 32 & 39.5 & 80.1 & 74.5 & 68.8 \\
\hline
\end{tabular}

Data ini diambil bukan untuk membandingkan karakteristik produk yang dikeringkan, melainkan untuk melihat performansi alat melalui pencapaian suhu keluaran dari kolektor tabung vakum (outlet ETC) selama proses pengeringan berlangsung.

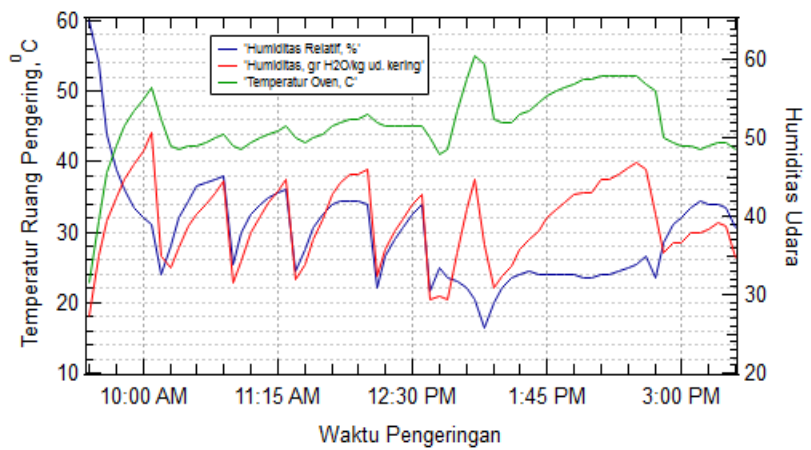

Gambar 7. Kondisi Temperatur, Humiditas Relatif dan Humiditas Mutlak di dalam Ruang Pengering (Run-1)

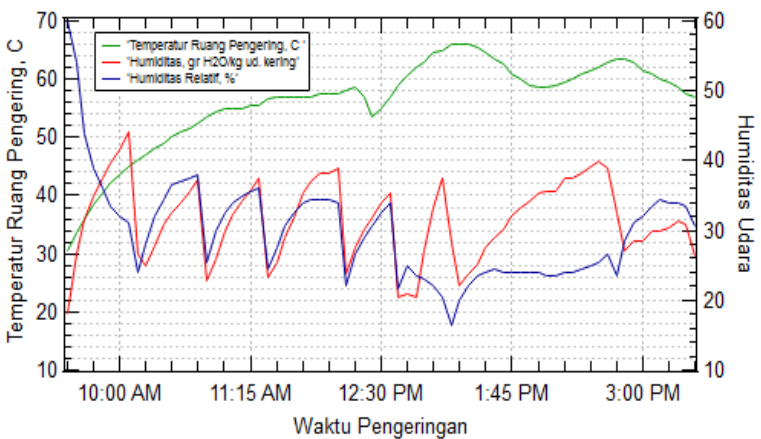

Gambar 8. Kondisi Temperatur, Humiditas Relatif dan Humiditas Mutlak di dalam Ruang Pengering (Run-2)

\section{Pengaruh $\mathbf{R H}$, Temperatur dan Humiditas Mutlak terhadap Proses Pengeringan Biji Kopi}

Pengaruh $\mathrm{RH}$ dan temperatur terhadap kinetika pengeringan menjadi bagian terpenting dari proses pengeringan. Semakin tinggi suhu dan semakin rendah $\mathrm{RH}$, maka laju pengeringan akan semakin meningkat (Inazu et al., 2002).

Hasil pengukuran profil temperatur dan humiditas relatif selama pengeringan berlangsung seperti disajikan pada Gambar 7 dan Gambar 8 menunjukkan bahwa 
temperatur dan humiditas relatif didalam ruang pengering menunjukkan pola yang berbanding terbalik. Semakin tinggi suhu didalam ruang pengering yang berbanding lurus terhadap waktu dan intensitas radiasi

Humiditas mutlak rill merupakan sifat termodinamika udara yang menggambarkan kondisi kemampuan udara pengering menerima proses perpindahan massa uap air yang dilepaskan dari kopi selama proses pengeringan berlangsung ( $\mathrm{Hii} \mathrm{CL}$, dkk, 2012). Nilai humiditas mutlak diperoleh dari pembacaan langsung grafik psikometrik atau dari perhitungan sifat termodinamika udara.

Dari Gambar 7 dan 8 terlihat humiditas mutlak memberikan pola naik dan turun selama waktu pengeringan. Hal ini sesuai dengan mekanisme proses pengeringan yang merupakan proses perpindahan panas dan perpindahan massa yang berlangsung secara simultan. Ketika tekanan uap air didalam kopi lebih tinggi dibanding pada interface permukaan kopi dan udara, maka uap air akan berpindah dari permukaan kopi ke udara menyebabkan suhu kopi menurun dan selanjutnya proses perpindahan panas diperlukan untuk menaikkan kembali suhu biji kopi sehingga uap air berdiffusi ke permukaan (Van Belleghem M., dkk, 2011).

Pada saat yang bersamaan adanya konveksi paksa, menyebabkan udara yang sudah jenuh dengan uap air, digantikan dengan udara kering yang sudah dipanaskan dan seterusnya kembali proses perpindahan massa uap air berlangsung kembali hingga berat air didalam kopi mencapai keseimbangan .

Kondisi pada Run-2 (Gambar 7) berlangsung pada suhu udara yang lebih tinggi dibanding Run-1 (Gambar 8), sejalan dengan nilai intensitas radiasi yang lebih tinggi selama proses pengeringan (Gambar 5 dan 6). Semakin tinggi intensitas radiasi, humiditas mutlak udara semakin rendah. Kondisi ini memberikan peluang uap air untuk berpindah lebih banyak dari kopi ke udara (Ondier dkk, 2010).

\section{Performansi Pengering Ditinjau dari Profil Penurunan Berat Biji Kopi Selama Pengeringan}

Di Indonesia biji kopi (jenis Arabica) yang telah dipanen kemudian difermentasi secara alamiah. Biji kopi yang telah dilepas dari kulitnya kemudian dikeringkan dari kadar air awal sekitar 80\%. Biji kopi ini biasanya dikeringkan dengan penjemuran langsung dan selanjutnya dikeringkan dengan pengering rumah kaca hingga kadar air mencapai $12 \%$. Proses pengeringan ini biasanya menghabiskan waktu hingga 3 (tiga) hari (Siagian P, dkk, 2017).

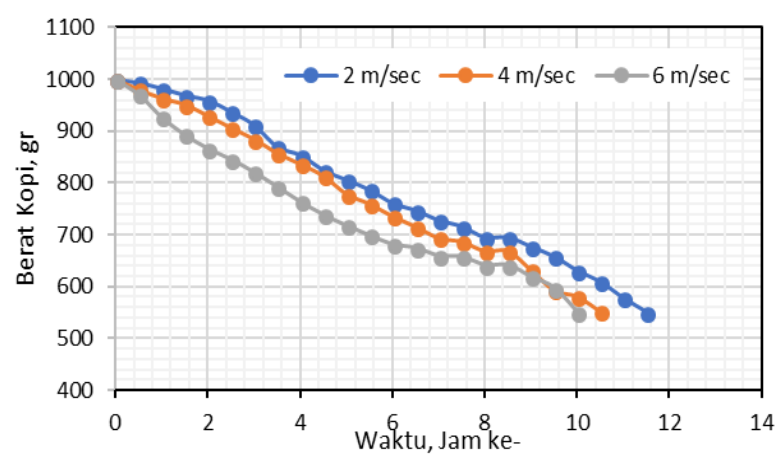

Gambar 9. Perubahan Berat Kopi Selama Pengeringan pada Berbagai Kecepatan Aliran Udara

Profil penurunan berat kopi selama pengeringan diperlukan untuk melihat performansi pengering kolektor tabung vakum hasil pabrikasi pada kecepatan aliran udara yang divariasikan. Biji kopi yang digunakan memiliki kadar air awal adalah 52,80\%. Data penurunan berat kopi pada varisi kecepatan aliran udara pengering 2, 4 dan $6 \mathrm{~m} / \mathrm{sec}$ disajikan pada Gambar 9. Dari data hasil percobaan menunjukkan bahwa semakin tinggi kecepatan udara maka waktu pengeringan yang diperlukan akan semakin singkat. Untuk mendapatakan kadar air akhir sekitar 12,10 - 12,30\% (basis kering) diperlukan waktu pengeringan pada kecepatan aliran udara 2, 4 dan $6 \mathrm{~m} / \mathrm{sec}$ berturut-turut adalah 670, 630 dan 600 menit. 
Sari Farah Dina Siti Masriani Rambe Azwardi

Edwin Harianto Sipahutar
Dari rancang bangun dan uji coba yang telah dilakukan dapat diambil kesimpulan bahwa rasio luas kolektor terhadap volume ruang pengering adalah 5,9 dan lebih besar dari 3 , sehingga desain ini memberikan efek perpindahan panas lebih baik.

Selama uji coba pengeringan kondisi cuaca rata-rata berada pada rentang 143$855 \mathrm{Watt} / \mathrm{m}^{2}$, temperatur lingkungan $28-35$ ${ }^{\circ} \mathrm{C}$. Temperatur udara didalam kolektor 85 $192{ }^{\circ} \mathrm{C}$ dan temperatur didalam ruang pengering adalah $35-78{ }^{\circ} \mathrm{C}$. Secara keseluruhan dapat terlihat bahwa nilai ratarata temperatur kolektor tabung vakum dan ruang pengering sangat dipengaruhi oleh intensitas radiasi yang memanaskan kolektor.

Hasil rancang bangun pengering surya menggunakan kolektor tabung vakum dengan sistem konveksi paksa yang memvariasikan kecepatan udara 2-6 m/sec digunakan untuk mengeringkan kopi dari kadar air 52,80\% hingga kadar air 12,30\%. Hasil uji coba menunjukkan bahwa kecepatan udara berbanding terbalik dengan waktu pengeringan.

\section{UCAPAN TERIMAKASIH}

Ucapan terimakasih penulis sampaikan kepada semua analis, peneliti,perekayasa serta seluruh manajemen Baristand Industri Medan yang telah banyak memberi dukungan sehingga penelitian ini dapat diselesaikan.

\section{DAFTAR PUSTAKA}

Darshit, P. dan G.D. Agawal (2011), Solar Drying in Hot and Dry Climate of Jaipur, India, International Journal of Renewable Energy Research, 1(4): 224-231

Fudholi A., K. Sopian, M.H. Ruslan, M.A. Alghoul, M.Y. Sulaiman (2010), Review of Solar Dryer for Agricultural and Marine products, Renewable and Sustainable Energy Reviews, 14: 1-30.

Hii CL., Jangam SV., Ong SP., Mujumdar AS., (2012), Solar Drying: Fundamentals,
Applications and Innovations, ISBN: 978981-07-3336-0, Published in Singapore.

Hossain, M.S., Saidur, R., Fayaz, H., Rahim, N.A., Islam, M.R., Ahamed, J.U., and Rahman, M.M. (2011), Review on Solar Water Heater Collector and Thermal Performance of Circulating Pipe, Renewable and Sustainable Energy Reviews, vol. 15: 3801-3812.

Inazu T., Ken-icji Iwasaki and Takeshi Furuta (2002), Effect of Temperature and Relative Humidity on Drying Kinetics of Fresh Japanese Noodle (Udon), Elsevier Science Ltd, doi: 10.1006/fstl.2002.0921.

Jangam SV.,Law CL., Mujumdar AS., (2010) Drying of Foods, Vegetables and Fruits, Volume 1, ISBN: 978-981-08-6759-1, Published in Singapore.

Jinap S., J. Thien, and T.N. Yap (1994), Effect of drying on acidity and volatile fatty acids content of Cocoa Beans, Journal of the Science of Food and Agriculture, no. 65, pp. 67-75.

Lamnatou C., Papanicolaou E., Belessiotis V., Kyriakis N (2012), Experimental Investigation and Thermodynamic Performance Analysis of a Solar Dryer Using an Evacuated-Tube Air Collector, Applied Energy, vol 94: 232-243.

Ondier GO, Siebenmorgen TJ, Mauromoustakos A., (2010), Low-Temperature, LowHumidity Drying of Rough Rice, Journal of Food Engineering Vol. 100, p: $545-550$.

Saravanakumar, P.T. and K. Mayilsamy, (2010), Forced Convection Flat Plate Solar Air Heaters With and Without Thermal Storage, Journal of Scientific and Industrial Research, 69: 966-968.

Siagian P., Eko Y. Setyawan, Tumiur Gultom, Farel H., Himsar A., (2017), A Fiels Survey on Coffee Beans Drying Methods of Indonesian Small Holder Farmer, $1^{\text {st }}$ Nommensen International Conference on Technology, IOP Conference on Technology and Engineering, IOP Conf. Series: Materials Sciences and Engineering, doi:10.1088/1757899X/237/1/012037.

Sundari Umayal A.R., Neelamegam P., Subramanian C.V., (2013), Performance of Evacuated Tube Collector Solar Dryer with and without Heat Sources, Iranica Journal of Energy \& Environment 4 (4): 336-342. 
Van Belleghem M., Steeman M., Willockx, Janssens A., De Paepe M., (2011), Benchmark experiments for moisture transfer modelling in air and porous materials, Building and Environment, Vol 46: $884-898$.

Venkatesan N, Arjunan T.V., (2014), An Experimental Investigation and Performance Analysis of a Solar Drying of Bitter Gourd Using an Evacuated-Tube Air Collector, International Journal of Chem Tech Research, Vol. 6, No. 14: 5510-5518 